\title{
Onomastics, Medicine and Politics in Femi Osofisan's The Engagement
}

\author{
Ayokunmi O. Ojebode \\ Redeemer's University, Ede, Nigeria \\ Idowu O. Odebode \\ Redeemer's University, Ede, Nigeria
}

\begin{abstract}
Onomastics, medicine and politics in this study are a pragmatic way of depicting the psychosocial condition of Nigeria as an underdeveloped nation. The study explores Femi Osofisan's The Engagement from a literary onomastic standpoint with the aim of exposing socio-political anomalies in Nigeria. Nigerian leaders commit flaws of egoistical and individualistic interests which often go against the consciences of the led. On this premise, the study explores the characters' names in The Engagement with a view to gaining insight into Nigeria's sociocultural and political contexts. Furthermore, Postcolonial Theory and Halliday's Contextual Theory of Meaning serve as the study's theoretical constructs. The study is predicated on the underdevelopment of Nigeria which is epitomised as a psychological behaviour of characters in a nation that is under the siege of political anarchy and different social vices.
\end{abstract}

Index Terms - medicine, Nigeria, onomastics, osofisan and politics

\section{INTRODUCTION}

Femi Osofisan is one of the few authors whose works have not enjoyed criticisms from literary-onomastic researchers. This study will thus break the silence cum the dearth of Onomastic (study and science of names) research of Femi Osofisan's The Engagement. To achieve this feat, the study fuses Postcolonialism (psychosis) and Halliday's Contextual Theory of meaning as theoretical constructs. The reason for their selection is because the underlining themes of the text resonate political as well as medical orientation, which can be best appreciated through the instrumentality of charactonymy in a context of situation.

A Synopsis of the Text

The Engagement by Femi Osofisan is an adaptation of the short play, The Marriage Proposal by the Russian playwright, Anton Chekhov. The play is a farce which features a marriage proposal by a timid and hypochondriac young farmer, Elemude and Ronke, his neighbour's (Medayekan) daughter. During Elemude's visit to Medayekan's house, he is reluctant to express his intention; until he is nudged, is he able to regain his confidence. Shortly, Ronke surfaces to meet the timid Elemude. The duo sooner starts an argument over the ownership of a particular land. This attracts the interest of Ronke's father who tries to prevail over the situation. Medayekan is unsuccessful in calming the duo due to Elemude's obstinacy in spite of his poor health. As the play continues, Elemude faints and he is presumed dead. It is after this incident that Medayekan reminds Ronke of Elemude's proposal. After a while, Elemude regains consciousness, yet, he continues arguing until Medayekan releases both discordant lovers to marry each other.

\section{Methodology}

Postcolonial Theory and Halliday's Contextual Theory of Meaning serve as theoretical constructs for this study. The term postcolonial psychosis is a coinage from some tenets of Postcolonialism and partly Psychoanalysis. It is adopted in this study to explore the medical (psychiatric) topography of the selected play. Meanwhile, Halliday's Contextual Theory of Meaning with emphasis on the Yoruba naming tradition is used to analyse three (3) characters' names in Femi Osofisan's The Engagement (henceforth, TE). Also, the concept of satire is examined through the characters' names in the selected text which is then used as a paradigm to critique issues of underdevelopment in the Nigerian society.

\section{A. Literature Review}

Postcolonial Theory constructs its tenets on some aspects of social histories, cultural differences and political discrimination motivated by Eurocentric structures. In addition, the theory focuses on anti-colonial reaction as crux of its ideology which is duplicated in the works of literary and political critic especially, Femi Osofisan. The aim of postcolonial critique as evident in the works of the author is to provide a foray into the decolonisation of the minds of citizens of 'Third-world' states in view of exposing colonial and neo-colonial impacts, and essentially, to advocate for the socio-political and economic integrity of such states. 
A number of theorists share this view, including Gayatri (1988); Bhabha (1988) and Ashcroft et al (1989). Our argument in this study is that, the Postcolonial Theory is a construct to reconcile history with contemporary realities particularly, with respect to Nigeria's naming tradition and modern politics. On this premise, the present discourse focuses on neo-colonialism manifesting as socio-political, economic and religious dysfunctions in post-independent Nigeria.

The thrust of this study is thus, on the negative effects of post-colonialism on the colonised states resulting in 'psychosis' or distorted view of reality. It is a form of 'hybridity' as postulated by Mohan (2006), exhibited by characters in such states in an attempt to relate with Western and their indigenous consciousness at the same time (cited in Adeyemi, Bisiriyu and Abarowei, 2016, p. 58). This conflict on the choice of 'consciousness' is the bedrock for postcolonial critics to enlighten their readers on the consequences of colonialism/neo-colonialism using literary texts.

Postcolonial psychosis is a term adapted from a study carried out by Adeyemi, Bisiriyu and Abarowei to describe the psychological trauma of people who have survived the colonial era as epitomised in the works of Osita Ezenwanebe's Withered Thrust and Helon Habila's Measuring Time. Their study and the present however differ in the aspect of conceptualising Postcolonialism. Their study is on colonial criticism whereas, the present study is on military and postmilitary criticisms and their implications on the political history of Nigeria through Femi Osofisan's The Engagement. The present study therefore, appraises the military and post-military eras with a view to gaining insight into the psychosocial experience of Nigerians.

Osofisan indigenously tackles political issues and imbalance of neo-colonial leaders in Nigeria without the intent of duplicating Eurocentric ideologies in his works, thus, he transports certain cultural practices of Nigerians into contemporary socio-political discourse of Nigeria. In this regard, a postcolonial critique of his work is thus, not a total demarcation of the old from the new, but instead, it is an attempt by the playwright to blend the old and new eras. Later in this study, the researcher, will unearth how Femi Osofisan deploys deep-rooted and metaphoric traditional names which have sociocultural implications in Nigeria to function beyond their original meanings in order to satisfy his satirical intent.

\section{B. Halliday's Contextual Theory of Meaning}

Michael Halliday's Systemic Functional Linguistics (SFL) inspired the Contextual Theory of Meaning that is, context of culture and situation in the mid-19th century and it is particularly the focus of applied linguists. The theory amplifies how certain conditions trigger variation of meaning and supply treasured information to understand the meaning of a text. Halliday's context of culture exposes the cultural background of the language used in the process of decoding the intended meaning of a text. Meanwhile, the context of situation basically implies "the environment of a text" (Halliday and Hassan, 1989, p. 46). For this study, the cultural milieu of Nigerians and the circumstances surrounding the production of a name is our concern.

\section{Literary Onomastics}

Onomastics is derived from a Greek word onomastikós 'onomastics,' an offshoot of ónoma, 'name.' It is the study of meanings and origins of names (Hajdú, 2002, p. 7). Allagbé, conceptualises "literary onomastics" as the semantic significance of a character's name in alignment with his/her role in a work of literature (p. 20). To understand the meaning of a name in a literary discourse such as this, the sociocultural significance of a name must be amplified over its linguistic significance.

As a corollary, a literary onomastician exposes the meaning of a name by tracing it to its root that is, the oral naming tradition of a particular community (sociocultural context) where it is produced. Thus, a character's name in a literary text cannot be interpreted in isolation of culture. Meanwhile, characters' names in the selected text are situated within the Yoruba cultural milieu. Our argument in this study is that, characters' names in Osofisan's TE are banks of information which share deep connection with Nigeria's historicity, politics and sociocultural beliefs.

\section{Satire}

Femi Osofisan like many other Nigerian playwrights uses satire as an artistic mode of expressing the social reality in contemporary Nigeria. The use of satire in the selected text is intentional as the playwright attempts to mock the 'insanity' and 'recklessness' of Nigerian political leaders through his characters. Satire is a traditional weapon in the hands of the powerless against the powerful. Thus, it is the artist's mode of assessing an existing socio-political system. In the same vein, Bloom (1979) postulates that a satirical work derides vices, crimes and absurdities of men and individuals, of class and organisations, societies and civilisations (p. 49).

In view of the above definition, Femi Osofisan in The Engagement (1995) employs satire to ridicule the foibles of leaders/institutions within the Nigerian society across themes of class stratification, political instability, ethnic prejudice, land and culture conflicts in a context of marriage between Ronke and Elemude. Failed expectation and contradiction of both military and civilian administrations in Nigeria are further typified through the characters of Chief Medayekan and Elemude in TE. It would be discovered from our analysis that the deployment of humorous characters' names and actions within the selected text is purely an ideological strategy by Osofisan to excite and incite his readers to ponder on national issues that threaten amity in the Nigerian society.

\section{E. Hypochondriasis as a Satire of Social Psychosis in Nigeria}


African playwrights write about medical conditions whether physiological or psychological to satirise negative human experiences within the society, particularly, the masses who are apparently oppressed and beleaguered under tyrannical and repressive leadership. During the dialogue between Chief Medayekan and Elemude at the Chief's house, the latter comments, "Sir...I'm in such a state of nerves, as you can see..." (TE, p. 3). Again he attempts to summon courage as he relays his intention in seeking for his daughter's hand in marriage, he says, "I'll tell you straight away. The fact is...bissimilai! That fact is that...have come sir! (TE, p. 3). It was after a nudge by Ronke's father that he manages to relay his intention. While he is alone, Elemude reveals the reason for his restlessness which is apparently beyond the proposal, he suffers a medical ailment, which is identified in this study as 'hypochondriasis'.

Elemude: I'm in such a state that I'm beginning to hear noises in my head...(Drinks water hastily). I've developed this terrible heart disease. I flare up so easily, at the smallest provocation, and it's my heart which suffers the consequence... until I can find a song to calm me down! You see? Even now, my lips are trembling, and my right eyelid is twitching... No sooner do I get into bed and start dropping off to sleep that something stabs me in my left side...(TE, p. 8).

Hypochondriasis is a psychiatric condition in which a patient is afraid s/he has contracted a critical ailment even when it is untrue. According to the American Psychiatric Association (2000), hypochondriasis (HC) is a psychologically-induced condition of a patient who has symptoms of physical disease but with no organic cause (p. 2). In such a case, the patient out of anxiety may constantly seek for medical examinations (Schmidt, 1997, p. 214). In Osofisan's TE, Elemude complains that he developed a terrible heart disease as a result of tireless labour on his farm (TE, p. 7).

In $T E$, Elemude complains about having a heart disease which according to him is accompanied by several other symptoms such as; continual palpitation, short temper, absence of self-coordination, trembling lips, twitching eyelids, insomniac experiences at night (TE, p. 7) and paralysis (TE, p. 36, 40). He further complains that Medayekan's sitting room is cold (TE, p. 11), and that it suffocates him (TE, p. 36), he also cites that he experiences flashes in his head (TE, p. 18).

Chief Medayekan similarly exhibits symptoms of ailment, probably, due to old age or an undisclosed sickness. In the text, he requests thrice for a glass of water because he feels dizzy, suffocated and he is about to faint after engaging Elemude in a vehement argument. Meanwhile, Ronke comments that she is about to faint out of exhilaration about Elemude's proposal. Her supposed sickness is pretentious and in a bid to pressurise her father to seek Elemude's recall (TE, p. 26).

\section{F. Argument as a Satire of Conflict in Nigeria}

Argument in the play has been artistically used by the playwright to expose the conflict of interests among Nigerian leaders. The first instance is the disagreement between Elemude and Ronke, and Chief Medayekan who later joins them to argue on the ownership of a particular farmland. The discussion between Elemude and Ronke is first on the ownership of land before it degenerates into which individual has the better dog. It is obvious that the subject of discussion by the duo are sheer irrelevancies which indicate the cluelessness of the characters on the valid history of the disputed land. Interestingly, the conflict among the characters parodies past and current crises in Nigeria and the consequence of ignoring trivial and unaddressed conflicts. First, was the Niger-Delta uprising which led to several kidnappings and destruction of properties which at first, was assumed to be reaction against the neglect of the Federal Government by natives of oil-infested States. However, not quite long after the first crisis came the advocacy for the Biafran state by some groups from Eastern Nigeria. Currently, the Nigerian government is combating a propagandist movement known as Boko Haram ('Book is forbidden') with underlined agenda of islamising Nigeria. In sum, argument/agitation as demonstrated in $T E$ breeds confusion instead of construction in a society/state.

\section{G. Land Conflict as a Satire of the Ongoing Fulani Herdsmen Uprising in Nigeria}

Another crucial theme in $T E$ is land ownership/control which is a parody of current uprising between the Fulani pastoralists and farmers in some locales in Benue State, Nigeria. At a time, the herdsmen claimed that the reason behind ransacking some villages in the North-Central, Nigeria is to retaliate the killing of their livestock. Currently, the Fulani herdsmen have transformed into henchmen for some powerful political cabals in Nigeria. In the same vein, the rancour between Elemude and Ronke also turns messy to the extent that each party is bullying the other. A major concern in $T E$ is the disparate perspectives of two intended 'lovers.' On one hand, Ronke cites folktales and traditional poetry to authenticate her family as owners of the concerned land. On the other hand, Elemude perceives such practices as barbaric and uncivilised therefore, he counters Ronke's claim with land documents.

Although, the text does not reveal the authentic owner of the land, Osofisan, being an advocate of culture, however, capitalises on the contradiction to educate the readers on the gap between traditional and Western customs. The playwright exploits the scenario to advocate the recovery of lost cultural values and ethos in Nigeria. Meanwhile, Wole Soyinka similarly illustrates the theme of cultural revitalisation in The Lion and the Jewel.

\section{H. Political Psychosis as a Satire of Failed Leadership in the Nigerian Politics}


The dialogue between Elemude and Chief Medayekan reveals the latter as a retired soldier who as a result of embezzling public fund among other controversies was demoted unceremoniously from the army. This is captured in the following conversation from the text:

Medayekan: I'm not used to being spoken to in that tone, and so forth!...I'm almost twice your age, and I've been in the army..."

Elemude: What has been in the army got to do with this? Your mates are being promoted generals, even in retirement! But you, it's over other people's land you want to win your medals!" (TE, p. 22).

Elemude: "Chief Medayekan! We have always been honest men. At least none of us was ever tried for embezzling money, like a certain retired army paymaster that we know!” (TE, p. 23).

Elemude: And it's an open secret that you were sent out of the army in disgrace, because..." (TE, p. 24)

The above excerpts indicate that Medayekan was formerly a military personnel before taking up his new-found status as an established agriculturalist which he probably, procured through corruption. Meanwhile, he still retains his military-like charisma. In the heat of Medayekan's anger, he threatens to lock Elemude in prison or shoot him if he did not take caution with his utterances:

Medayekan: He's just a malicious, double-faced, thieving fellow! Just the type for Kirikiri Maximum Security Prison..." (TE, p. 25).

Medayekan: Hold your tongue, I say! Or I'll shoot you like some miserable rat... (TE, p. 37).

Osofisan, through the artistic creation of Chief Medayekan, alludes to the military era in Nigeria from $15^{\text {th }}$ January, 1966 to $29^{\text {th }}$ May, 1999. The military leaders were initially celebrated as 'messiahs' who have come to rescue the polity from corrupt politicians following the collapse of the first democratically-elected government in 1966.

Quite understandably, military leaders were initially associated with superfluous charisma and magical potentials. It is in the same light that so-called 'native Africans' esteem past colonial rulers, who in the words of Ekeh (1978) were "perceived by most Africans in magico-religious terms, to have come to dispense good life" (p. 327). Thus, the military were seen as succour to the failings of politicians who took over power from the imperialists in 1960. However, the military intervention that Ademoyega (1981) describes as a "painless surgical operation designed to heal a disabled Nigeria" (p. 126) turns out to be a lethal injection. Shortly after the arrival of the military in the national politics in the 1980s and 1990s, Nigeria began to experience cataclysm especially, in the political and economic sectors. It became increasingly clear that the military had no solution to the myriad of problems that it intervened to tackle such as parlous economy, decayed infrastructure, poverty, corruption, ethno-religious conflicts and nepotism among other ills. Osofisan's $T E$ draws the attention of the readers to the disfigured union of two individuals who are meant to be married, and in which one of them is fathered by a megalomaniac and self-important ex-military man.

Overall, Osofisan's selected text exposes different levels of lawlessness and hardship inflicted on the nation and its citizens by the military. The psyche of many Nigerians has been bruised, while some others have suffered individually and collectively. He demonstrates through $T E$ that the intervention of the military does not qualify them as 'saints.' In sum, the selected text indicts the government either military or civilian, as agents of discord and moral decadence in the Nigerian society.

\section{RESULTS AND ANALYSIS}

\section{A. Real/Marxist Name}

Chief Medayekan in $T E$ is a retired soldier, agriculturalist, musician and father to Ronke. Meanwhile, Chief is the titular name for a paramount ruler over a particular locale. Osofisan uses the character to symbolise the bastardisation and commercialisation of traditional institution in Nigeria. The traditional institution used to be respite of the people for truth and justice. Traditional institutions conferred on people of proven integrity chieftaincy titles to recognise and honour them. Nowadays, the once revered institution however, has been turned into a commercial avenue where the highest bidder gets the titles. Fraudsters and 'philanthropists' who have money and wherewithal to buy the title are now the ones conferred with it. Osofisan portrays this sad situation in TE as Medayekan, a corrupt ex-military officer uses money to acquire a ridiculous chieftaincy title and a decent life for himself. Through the character, the playwright conveys the idea that chieftaincy titles are now being used to elevate people from the proletariat to bourgeoisie social class in Nigeria.

Furthermore, Medayekan's name sounds like Mo d' ile aye d'ekan (I arrived the world in affluence/born to be prominent) in Yoruba. It may connote an affirmation of one's good fortune, a natural, rather than an achieved endowment. The character's name probably, has a Marxist undertone with respect to Medayekan's portrayal as a corrupt ex-military officer. Considering Chief Medayekan's antecedent with the military, Osofisan uses this character's name to parody the military era in Nigeria, and to take an indirect swipe at former military Heads of State who turned civilian. Chief Olusegun Obasanjo aptly fills this category, as a former military general and President of Nigeria who turned a large-scale agriculturalist in Ogun State, Nigeria.

Most importantly, Chief Medayekan's name distinguishes the character as a type of bourgeoisie as against Elemude's name. In fact, his first impression at the clumsy arrival of the latter character at his house is that he has come to borrow money. A careful observation of the characters' names indicate that they are 'onomastic strategies' intentionally 
deployed by Osofisan to distinguish characters and their roles in the text and also, exhibit the cultural milieu of the playwright.

\section{B. Real/Gender Name}

Ronke in the Yoruba culture denotes, 'I have found someone to pamper, nurture or care for.' She as the only daughter of Chief Medayekan enjoys all the attention and care lavished on her by her father. Her name complements her role as she freely expresses her opinion and marital choice which contrasts the traditional Yoruba patriarchal society. She is indeed, the centre of Medayekan's world, his music partner and history-preserver. She sings and recites all the folktales and stories to counter Elemude's claim to a disputed farmland every time she is needed.

In fact, at the end of the play, after she has realised the purpose of Elemude's visit, she uses her position and feminine sway to succumb her father to recall Elemude back to their house, even when it is against his will. Most importantly, the traditional Yoruba issue names that reflect care, nurture and pampering to the female child (Akinyemi, 2016, p. 6).

Thus, according to the above exposition on the peculiarity of feminine character's name, it would be negligent of Medayekan to deny his daughter care within the Yoruba context of her name. Consequently, the playwright's feminist inclination is expressed through the character's name. Her name probably, indicates the need for females to alter the stereotype attached to their gender in the African society.

\section{Satiric/Psychological/Literary Name}

Elemude is a neighbour to Medayekan. He is also, a young farmer, musician and Ronke's suitor. Contextually, the name is ambiguous. First, it denotes "the captor has arrived" and second, by punning the name, it would denote "the palm wine drunkard has arrived." As a captor, he has come to catch a lady and as a drunkard, he drinks. For clarity, palm wine is a white traditional liquor extracted from the trunk of a palm tree by a tapper in many cultures in Nigeria, especially, the Yoruba and Igbo ethnic groups. Contextually, the character's name alludes to a major function of the liquor apart from personal consumption, it is also served to entertain guests at engagement/marriage ceremonies in Southwest, East and South-southern Nigeria respectively.

An aphorism among the Yoruba people complements Elemude's rabblerousing traits, Omuti gbagbe ise, o da 'keregbe o da'keregbe bori. It implies, 'a drunk forgets his penury till he forgets a gourd/calabash on his head.' Thus, this statement sheds more light on the utensil used to traditionally dish out and preserves palm wine. Unsurprisingly, the first encounter of the reader with the character of Elemude is an unstable, deranged and uncoordinated individual. His over-nervousness, girlish demeanour and reluctance to share his intention with Medayekan on the proposal to his daughter reveal a spineless coward with low-self-esteem.

Also, he quickly forgets his purpose of visit at Medayekan's house as he expresses rage each time he is challenged by Ronke on the ownership of a land adjoining theirs which he lays claim on. It has been pointed out earlier in the study that it seems Elemude suffers from a psychological disorder of 'hypochondriasis,' hence, the reason for his being hyperactive and obsession about having different symptoms of sickness that he exhibits. At a point, he feels pains in his head, leg, chest, eyes and other parts of his body without admittance to any in particular, he feels better only when music is therapeutically used on him

This aspect indicates the importance of music to Africans, especially, in the Yoruba tradition. Music goes beyond the purpose of entertainment, Medayekan uses music to entertain Elemude at his arrival in his house, but, as events unfold, music is also used to recount and recall ancient folktales that define Medayekan's family as the owner of a disputed land, which is record-keeping. Similarly, music in the Yoruba culture is also used to appease and provoke emotions of the combating parties during the time of war. Fascinatingly, in many Yoruba palaces, songs are, as well, used to appease, eulogise, wake, jest, celebrate or spur kings into their daily activities early morning. It is often sung by 'Queens' (Olori), 'personal servants' (Ilari, so called because they draw a line between a half of their head neatly shaved and the half that is left unshaven), praise singers or 'royal chanters' (Akéwi). In the ancient Oyo, it is the duty of the court drummers and akéwì at the Òyó palace to wake up the king (i.e. Alaafin) with praises every day (Owolabi and Alagbe, 2008, p. 20).

Music interlinks with the character's name to reinforce his erratic traits which is similar to a winebibber's. Also, his name distinguishes him as a troublemaker who can disrupt a peaceful setting anytime he shows up. Furthermore, his name connotes someone that people should be wary of. A closer look at Elemude's name reveals that it is a satirical name which carries psychological implication on its bearer. It is not a generic name that people bear in the Yoruba milieu. Therefore, the playwright demonstrates an artistic ingenuity by designing the name to mock some leaders in Nigeria, hence the political theme underlining the text.

In this regard, Elemude's name may imply the nonchalant, indifferent and paedophilic nature of Nigerian politicians to taking critical decisions on certain issues of national interest. Thus in the process, they disrupt and desecrate the ancient landmarks of tradition and culture. We can therefore, claim that Chief Medayekan and Elemude's name parody some Nigerian politicians who propagate and instigate ethnic rivalry. Overall, Elemude proves the alcoholic feature inherent in his name by his non-comportment and ineptitude displays. He thus, fulfils the destiny attached to his name.

\section{DisCUSSIONS AND CONCLUSION}


By exploring names in Osofisan's TE, we have drawn a converging line among the variegated fields literature, history, culture, medicine and political studies. Characters' names have been unveiled in the study as sources for postcolonial discourses which are relevant to the political history of Nigeria, and also form bedrock to interrogate the psychiatric condition of 'hypochondriasis.' As discovered in the study, the ailment serves artistic, literary, satiric, political and medical purposes which typify contemporary Nigerian 'caricatured' political leaders. Summarily, hypochondriasis in $T E$ is used by the playwright to buttress themes of political instability and underdevelopment in Nigeria. On this premise, the study invites critics to further interrogate onomastic and allied tropes in other works of Femi Osofisan. Such researches and the present study, would then be an impetus for relevant socioeconomic and political discourses that can foster development in Nigeria.

\section{REFERENCES}

[1] Ademoyega, A. (1981). Why We Struck: The Story of the First Nigerian Coup. Ibadan: Evans.

[2] Adeyemi, O; Bisiriyu, A; Abarowei, F. (2016). "Postcolonial Psychosis and Recovery Process in Osita Ezenwanebe's Withered Thrust and Helon Habila's Measuring Time". Journal of Culture, Society and Development 24, 56-60.

[3] Akinyemi, A. (2016). "Names and Naming Characters in African-language Dramaturgy: the Yoruba Example, African Identities". DOI: 1472-5851 (Online) Journal homepage: http://www.tandfonline.com/loi/cafi20, 2016.

[4] American Psychiatric Association. (2000). Diagnostic and Statistical Manual of Mental Disorders (4th edn., text revision). Washington, DC: Springer Publishing Company.

[5] Ashcroft, B., Gareth G., and Helen T. (1989). The Empire Writes Back: Theory and Practice in Postcolonial Literature, London:

[6] Bhabha, H. (1998). "Location of Culture" In Literary Theory: An Anthology, Oxford: Blackwell Publishers.

[7] Bloom, E. (1979). Satire's Persuasive Voice. Ithaca: Cornel University Press.

[8] Ekeh, P. (1978). "Colonialism and the Development in Citizenship in Africa: A Study in Ideologies of Legitimation." Onigu, O. (ed.) Themes in African Social and Political Thought. Enugu: Fourth Dimension.

[9] Gayatri, S. (1988). In Other Words: Essays in Cultural Politics, London: Routledge, 209.

[10] Habila, H. (2006). Measuring Time. Cassava Republic Press Book, Abuja: Nigeria.

[11] Halliday, M. and Hasan, R. (1989). Language, Context and Text: Aspect of Language in a Social-Semiotic Perspective. Oxford: Oxford University Press. Print.

[12] Hajdú, M. (2002). "The History of Onomastics.” In Onomastica Uralica 7-45.

[13] Mohan, I. (2006). "Postcolonial Writing: Trends in English Drama." Indian Review of World Literature in English.

[14] Osofisan, F. (1995). The Engagement. Ibadan: Agbo Areo Publishers.

[15] Owolabi, K. \& S. Alagbe. (2008). The Alaafin of Oyo, Oba Lamidi Olayiwola Adeyemi III, His Life History and His Philosophy. Nigeria: Universal Akada Books.

[16] Schmidt, N., D. R. Lerew \& Trakowski, J. H. (1997). Body vigilance in panic disorder: Evaluating attention to bodily perturbations. Journal of Consulting and Clinical Psychology 65, 214-220.

[17] Soyinka, W. (1963). The Lion and the Jewel. Ibadan: Ibadan University Press.

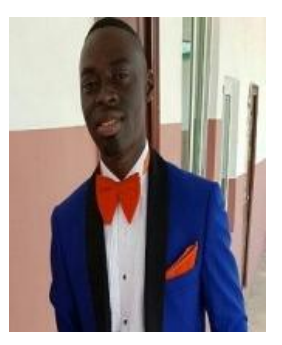

Ayokunmi Ojebode is a doctoral candidate in Department of English, Redeemer's University, Ede, Nigeria. $\mathrm{He}$ is a budding scholar with keen interest in Literary Onomastics and African literature. He can be contacted through: ojebodea@run.edu.ng

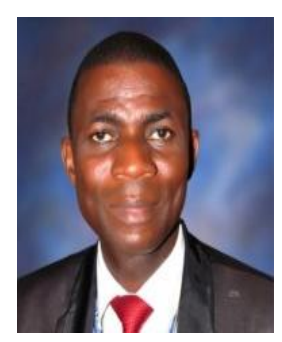

Idowu Odebode $(\mathrm{PhD})$ is a lecturer in Department of English, Redeemer's University, Nigeria. His areas of interest include Onomastics, Pragmatics and Discourse Analysis. He can be contacted through: iodebode@yahoo.com and odebodei@run.edu.ng 